\title{
The Import of Technology on English Language Learning in Tertiary Institutions: A Study of Lagos State Polytechnic, Ikorodu
}

\author{
1Ero-Philips, M.A. ${ }^{2}$ Adewumi, D.O. \& ${ }^{3}$ Akinkugbe, A.I. \\ ${ }^{1}$ School of Liberal Studies (English Unit) \\ 2Department of Office Technology and Management \\ ${ }^{3}$ School of Liberal Studies (English Unit) \\ Lagos State Polytechnic \\ Ikorodu, Lagos State, Nigeria
}

E-mails: 1ablaerophillips@gmail.com; 2adewumi.d@laspotech.edu.ng; firstamongequals1006@gmail.com

Phones: +2348023116696; +23480673945443; +2348033331577

\begin{abstract}
Modern Technology has to a great extent expanded knowledge in every sphere of disciplines with increased opportunities for students to learn new skills, especially, new languages. This paper has investigated and discussed the Import of Modern Technologies in the learning of English in a tertiary Institution such as the Lagos State Polytechnic. The focus of the paper is on the methods of innovative technologies available for learning English with ease. The study also identifies some gaps such as dearth of Language Laboratory, Students attitudes towards language learning and technology anxiety as factors that hinder an effective learning of the English language. Questionnaire was used as the major research instruments. Two hundred (200) respondents were used for the study. Samples were drawn from students of the Lagos State Polytechnic, fifty (50) students each from the NDI, NDII, HNDI and HND II levels were selected randomly, constituting a study population of two hundred (200) respondents. Data collected were presented in frequency tables and percentages, graphical representation were used to analyze, and discussions were made on each table and figure. Findings were presented and recommendations given base on the findings.
\end{abstract}

Keywords: Technology, English Language, Learning, Tertiary Institutions

Proceedings Reference Format

Ero-Philips, M.A. Adewumi, D.O. \& Akinkugbe, A.I. (2021): The Import of Technology on English Language Learning in Tertiary Institutions: A Study of Lagos State Polytechnic, Ikorodu. Proceedings of the 27th iSTEAMS Multidisciplinary Innovations \& Technology Transfer (MINTT) Conference. Academic City University College, Accra, Ghana. June, 2021. Pp 342 www.isteams.net/ghana2021. DOI - https://doi.org/ 10.22624/AIMS/STEAMS-2021/N27P29 